\title{
Developments
}

\section{Beyond the Binary: Towards a Third Sex Category in Germany?}

\author{
By Peter Dunne* \& Jule Mulder ${ }^{* *}$
}

\begin{abstract}
This Case Note discusses the recent judgment of the German Constitutional Court (1 BvR 2019/16) requiring either the legal recognition of sex categories beyond male or female, or the aboltion of sex registration requirements. The Note considers the Court's decision within the broader constitutional case law on gender identity, and explores both the progressive potential, and the future-perhaps unforeseen-consequences, of the ruling. The Case Note proceeds in three sections. Section A introduces the facts of the constitutional challenge, and sets out both the submissions of the complainant, as well as the reasoning of the Constitutional Court. In Section B, the Case Note explores the domestic law novelty of the decision, placing particular emphasis on the application of a constitutional equality framework to persons who experience intersex variance. Finally, in Section C, the Case Note contextualizes the judgment, situating the reasoning of the Constitutional Court within wider movements for transgender-otherwise known as trans ${ }^{1}-$ and intersex rights.
\end{abstract}

\footnotetext{
* Lecturer in Law, University of Bristol Law School, pd17563@bristol.ac.uk, http://www.bristol.ac.uk/law/people/peter-r-dunne/index.html.

** Lecturer in Law, University of Bristol Law School, jule.mulder@bristol.ac.uk, http://www.bristol.ac.uk/law/people/jule-mulder/index.html.

${ }^{1}$ Transgender or trans is an umbrella terms which refers to a person who does not self-identify with the legal sex that was assigned to them at birth.
} 


\section{A. Introduction}

In November 2013, Germany made worldwide headlines as the first European country that legally recognizes a "third sex" other than male and female and was celebrated for its progressive approach toward children who experience intersex variance. ${ }^{2}$ As is often the case, the reality was a lot less glamorous. Germany was by no means the first European country legally recognizing people who experience intersex variance. The Netherlands had already introduced similar rules in the 1970s. ${ }^{3}$ Moreover, while the implications of the change were uncertain-and criticized for potentially inducing parents to agree to surgical intervention to ensure that a legal sex can be assigned ${ }^{4}$ - the new law did not create a third legally recognized sex..$^{5}$ Section 22(3) of the Law on Civil Status-Personenstandsgesetz (PStG) ${ }^{6}$ - simply allows that newly born children can be registered without reference to their legal sex if "the child can neither be assigned the male nor the female sex." In that case, the specific sex reference on the registration form is left blank. The provision does not provide redress for those persons who wish to be acknowledged in a legal sex beyond male or female.

The narrow scope of section 22(3) of the PStG has now been subject to a successful constitutional challenge. In October 2017, the German Federal Constitutional Court-

\footnotetext{
${ }^{2}$ See, e.g., Jacinta Nandi, Germany Got It Right by Offering a Third Gender Option on Birth Certificates, THE GUARDIAN (Nov. 10, 2013), https://www.theguardian.com/commentisfree/2013/nov/10/germany-third-gender-birthcertificate; Friederike Heine, 'Third Gender' Official in Germany from November, SPIEGEL ONLINE (Aug. 16, 2013), http://www.spiegel.de/international/germany/third-gender-option-to-become-available-on-german-birthcertificates-a-916940.html; Germany to Become First European State to Allow 'Third Gender' Birth Certificates, RT (Aug. 17, 2013), https://www.rt.com/news/third-gender-birth-germany-592/; Amanda Scherker, Germany To Offer Third Gender Option On Birth Certificates, HUfFInGtON POST (Aug. 17, 2018), www.huffingtonpost.co.uk/entry/germany-third-gender_n_3769055. According to the (former) Intersex Society of North America, "intersex" "is a general term used for a variety of conditions in which a person is born with a reproductive or sexual anatomy that doesn't seem to fit the typical definitions of female or male." INTERSEX SOCIETY OF NORTH AMERICA, What is Intersex?, http://www.isna.org/faq/what_is_intersex (last visited Jan. 9, 2018).

${ }^{3}$ Marjolein van den Brink \& Jet Tigchelaar, Gender Identity and Registration of Sex by Public Authorities, 2 EUR. Equality L. ReV. 29 (2015); Marjolein van den Brink, Philipp Reu \& Jet Tigchelaar, Out of the Box? Domestic and Private International Law Aspects of Gender Registration: A Comparative Analysis of Germany and the Netherlands, 17(2) EUR. J. OF L. REFORM 282 (2015).
}

4 See id.; ZWISCHENGESCHLECHT.ORG, STOP Intersex Genital Mutilations in Children's Clinics, stop.genitalmutilation.org/post/Intersex-3rd-gender-in-Germany-Silly-season-fantasies-vs-reality-of-genitalmutilations (last visited Jan. 9, 2018).

${ }^{5}$ Nina Dethloff \& Susanne Gössl, Country Report for Germany, in M/V EN VERDER; SeKSEREGISTRATIE door DE OVERHEID EN DE JURIDISCHE Positie VAN TRANSGENDERS 137, 139 (Marjolein van den Brink \& Jet Tigchelaar ed., 2014).

${ }^{6}$ Nov. 1 2013, No. 21.4.3 Allgemeine VerWaltungsVorschrift ZUM Personenstandsgesetz [General Administrative Regulation on the Personal Status law].

${ }^{7}$ Personenstandsgesetz [PSTG] [LAW ON CIVIL STATUS], Feb. 19, 2007, BGBL I at § 22 para. 3 (Ger.). 
Bundesverfassungsgericht (BVerfG) - held that as long as the legislature continues to require the registration of legal sex, it had to allow for the positive registration of intersex persons who may identify as neither exclusively male nor female. ${ }^{8}$

In this Case Note, we discuss the BVerfG's judgment within the court's broader case law on gender identity. The case note considers both the progressive potential, and the futureperhaps unforeseen-consequences, of the judgment. The Case Note proceeds in three sections. Section A introduces the facts of the constitutional challenge, and sets out both the submissions of the complainant, as well as the reasoning of the Constitutional Court. In Section B, the Case Note explores the domestic law novelty of the decision, placing particular emphasis on the application of a constitutional equality framework to persons who experience intersex variance. Finally, in Section C, the Case Note contextualizes the judgment, situating the reasoning of the Constitutional Court within wider movements for transgender-otherwise known as trans ${ }^{9}$-and intersex rights.

\section{B. The BVerfG's Judgment}

The complainant in the case was registered as female at birth. They ${ }^{10}$ experience intersex variance, and do not identify as either male or female. The complainant sought to obtain legal recognition of either an inter or diverse sex marker on their birth certificate. The fact that the PStG does not allow such an option was the subject of the constitutional review. In their submissions, the complainant particularly emphasized that by requiring the registration of the male or female sex, the PStG forced upon them a binary understanding that did not reflect their own experienced sex. The newly introduced section 22(3) of the PStG did not solve this problem because it only allowed for the non-recognition of their legal sex; thus, it turns the complainant into a "nullum." While this may not have direct socioeconomic consequences, the complainant argued that non-recognition has a significant impact on identity development within the current social context. Moreover, the complainant challenged the current legal framework as discriminating against individuals who experience intersex on grounds of their sex. Such persons cannot have their legal sex registered, while the legal sex of men and women can be formally acknowledged. The rules

\footnotetext{
${ }^{8}$ Bundesverfassungsgericht [BVerfGe] [Federal Constitutional Court], Case No. 1 BvR 2019/16 (Oct. 10, 2017), https://www.bundesverfassungsgericht.de/SharedDocs/Entscheidungen/DE/2017/10/rs20171010_1bvr201916.h tml.

${ }^{9}$ Transgender or trans is an umbrella terms which refers to person who do not self-identify with the legal sex that was assigned to them at birth.

${ }^{10}$ The complainant prefers gender neutral "They/Them" pronouns, which the authors respect in this article.
} 
thus breached the right to free development of personality ${ }^{11}$ and the right not to be disadvantaged because of sex. ${ }^{12}$ The BVerfG agreed.

First, the court held that Article 2(1) of the German Constitution-Grundgesetz (GG)guarantees the right to personal development. While not every external aspect that may influence personal identity can be challenged under Article 2(1), it protects those elements of personal development that are of constitutive importance. This includes issues related to gender identity, including those identities that are not exclusively male or female. This is so because a person's legal sex is a key aspect of personal identity, feeds into expectations regarding appearance, and how a person is perceived and identified by others. The sex registration also has legal relevance. For example, in the context of passport applications, health insurance cards, and applications to universities or the civil service. ${ }^{13}$

The court held that the current legal framework fails to protect the gender identity of those people who experience their sex as neither male nor female. This is because the PStG, on the one hand, requires registration of legal sex but, on the other hand, makes an accurate sex registration impossible. Specifically, the court rejected that section 22(3) of the PStG resolves the issue because it does not allow for the positive registration of the inter/diverse legal sex, and it suggests that it is only temporarily impossible to determine the legal sexas if it was only a matter of time until the legal sex can be registered. Thus, it does not recognize the complainant's preferred legal sex. ${ }^{14}$

Such lack of recognition significantly interferes with the right to free and individual personal development and gender identity. The sex registration system can endow and express certain gender identities and is significant within the current legal framework. Moreover, it influences how the individual is perceived by others in public and makes it difficult for persons who experience intersex variance to live a life reflecting their actual sex. The court did not identify any possible justification for the interference with the right to personal development. ${ }^{15}$

Second, the Constitutional Court held that the PStG discriminated against persons who experience intersex variance on grounds of their sex contrary to Article 3(3) of the GG. These individuals either have to tolerate an incorrect sex registration or a registration that suggests

\footnotetext{
${ }^{11}$ GRUNDGESETZ [GG] [BASIC LAW], arts. 1(1), 2(1), trans/ation at https://www.btgbestellservice.de/pdf/80201000.pdf.

${ }^{12} / d$. at art. 3(3).

13 Judgment of Oct. 10, 2017 at paras. 38-40.

${ }^{14}$ See judgment of Oct. 10, 2017 at para. 42.

${ }^{15}$ See judgment of Oct. 10, 2017 at paras. 45-54.
} 
that they do not have a sex at all. Thus, they suffer a disadvantage compared to people who identify as male or female and can be registered in accordance with their preferred legal sex. As such, sex within the meaning of the article does not only cover men and women, but also extends to additional experiences of identity. It does not only protect men and women who are disadvantaged because of their male or female sex, but also those who are disadvantaged because there is no possibility to register sex categories beyond male and female. ${ }^{16}$

In conclusion, the BVerfG suggested two alternative choices to rectify the constitutional infringement. The German legislature can either abolish the PStG's requirement to register legal sex, or it can create an additional option to be registered as a third sex. ${ }^{17}$ Thus, there is a positive obligation to recognize the existence of persons who experience intersex variance, either by creating an additional sex category or by abolishing sex registration all together.

\section{The Judgment's Novelty}

In many ways, the judgment confirms the existing case law on the rights of trans persons under Article 2 of the GG. The BVerfG assessment of the right-of persons who experience intersex variance to their own gender identity based on their experience of their sex-is widely based on the court's previous findings regarding the rights of trans individuals. Trans populations have been extremely successful in front of the BVerfG. As early as 1978, the court held that trans communities were entitled to obtain recognition of their preferred legal sex. ${ }^{18}$ The subsequently introduced Transsexuality Act $^{19}$ has been scrutinized on a number of occasions since $1980 .{ }^{20}$ In recent cases, the court has rejected provisions that

\footnotetext{
${ }^{16}$ See judgment of Oct. 10, 2017 at paras. 56-60.

${ }^{17}$ See judgment of Oct. 10, 2017 at para. 65.

18 Bundesverfassungsgericht [BVerfGe] [Federal Constitutional Court], 1 BvR 16/72, BVerfGe 49, 286 (Oct. 11, 1978).

${ }^{19}$ Transsexuellengesetz [TSG] [TRANSSEXUALITY ACT], Sept. 10, 1980, BGBL I at 1654, last amended by art. 1 of the Act, July 17, 2009, BGBL I at 1978 (Ger.).

${ }^{20}$ See, e.g., Bundesverfassungsgericht [BVERFGE] [FEderal Constitutional COURT], 1 BvL 1/04, BVerfGE 116, 243 (July 18, 2006) (detailing the nationality requirement); Bundesverfassungsgericht [BVERFGE] [FEDERAL CONSTITUTIONAL COURT], 1 BvR 938/81, BVerfGE 60, 123 (Mar. 16, 1982) (describing the minimum age requirement of 25-year-old); Bundesverfassungsgericht [BVERfG] [FEDeral Constitutional COURT], 1 BvL 3/03, BVerfGE 115, 1 (Dec. 6, 2005) (discussing the loss of the changed name after marriage).
} 
required trans persons to divorce, ${ }^{21}$ submit to sex confirmation surgery, or sterilization ${ }^{22}$ in order to obtain legal recognition of the gender they identify with. Regarding the latter, the court was explicit that a lesbian-identified trans woman-assigned male at birth-has the right to live in both the gender and the sexual identity she identifies with. She could therefore be recognized as a woman and live with her same-sex partner in a legally acknowledged same-sex union, without having to undergo sex confirmation surgery and its attending health risks.

All of these cases have been based on Article 2(1) of the GG-personal freedom-in conjunction with Article 1(1)-dignity-and created a substantive right towards recognition. Thus, Article 2(1) protects a person's right to their individual gender and sexual identity, imposes a duty on the state to recognize these identities that are not defined within the male/female dichotomy, and enable their expression as reflected within legal institutions. A focus on intersex rather than trans does not fundamentally change these conclusions developed in relation to trans rights-even if it is the first time that the court directly challenges the binary sex structure-upon which the law on civil status is based. The only difference in this case seems to be that the challenge to the binarity of gender identity is accompanied with a challenge to the binarity of the biological sex. It would make little sense to distinguish between both. There is no direct causation between a person's experience of intersex variance and a non-binary gender identity. On the one hand-unlike the plaintiff in the Third Option case-many persons with intersex variance identify as men or as women. On the other hand, some persons whose biological sex is verifiable within the male/female dichotomy, and who may or may not identify as trans, may experience a non-binary gender identity. Thus, it is not obvious why the former non-binary gender identity should now be recognized while the latter would continue to only be recognized within the binary structure. As discussed in Section C, previous case law on the right to gender recognition also focused on gender identity rather than biological or physical indicators. ${ }^{23}$ In any case, the court does not clearly distinguish between sex and gender in its assessment. Rather it seems to adopt the view taken by the German Psychological Society (Deutsche Gesellschaft für Psychologie), according to which gender is a multi-dimensional construct that is influenced by aspects of biology, psychology, and sexuality. ${ }^{24}$ The German word Geschlecht also does not directly distinguish between sex and gender and can refer to both. One novelty of the case thus

\footnotetext{
${ }^{21}$ Bundesverfassungsgericht [BVerfG] [Federal Constitutional Court], 1 BVL 10/05, BVerfGE 121, 175 (May 27, 2008).

22 Bundesverfassungsgericht [BVerfG] [Federal Constitutional Court], 1 BVR 3295/07, BVerfGE 128, 109 (Jan. 11, 2011).

${ }^{23}$ Chris Ambrosi, Die Dritte Option: Für wen?, VerfBlog (Nov. 29, 2017), https://verfassungsblog.de/die-dritteoption-fuer-wen; Bundesverfassungsgericht [BVERFG] [FEDERAL CONSTITUTIONAL COURT], 1 BVL 10/05, BVerfGE 121, 175 (May 27, 2008).

${ }^{24}$ See judgment of May 27, 2008 at para. 26.
} 
seems to be the possible recognition of a non-binary gender identity not just for intersex individuals, but more broadly. While previous case law allowed trans gender people to reassign their legal sex from male to female or vice versa, the current case focuses on recognition of identities that are neither male nor female.

Another potential novelty of the case seems to be its consideration of persons who experience intersex variance under the scope of Article 3(3) of the GG. ${ }^{25}$ The Article sets out the constitutional equality principle and prohibits favorable-or unfavorable treatmentbecause of sex/gender (Geschlecht) in paragraph 3. So far, the personal scope of "sex/gender" has been interpreted narrowly and suggested a predominant focus on the biological sex rather than gender. The court has not explicitly engaged Article 3(3) of the GG in considering the rights of trans persons and thus has not considered the rights of trans persons within a broader gender equality framework. Rights to enter same-sex civil unions that reflect the personal sexual identity-or to live in one's preferred gender without a requirement to divorce-were thus considered only within the margin of personal self-expression and identity.

Similarly, the rights of sexual minorities and predominantly same-sex couples have not been considered under the scope of Article 3(3), as the court draws a distinction between sex and sex combinations. ${ }^{26}$ While the first is protected under paragraph 3 , the latter is covered only under the general equality clause of Article 3(1). This has not stopped the court from significantly broadening the rights of same-sex couples after the introduction of same-sex civil unions. ${ }^{27}$ Nonetheless, the reach of the case law has been limited, as it does not situate the disadvantage of sexual minorities within a broader gender equality framework. A focus on gender could expose disadvantages suffered by sexual minorities, trans communities, and persons who experience intersex variance within the heteronormative legal framework that assumes binarity of sex, gender, and sexuality. ${ }^{28}$ There have thus been repeated suggestions to include gender expectations under the scope of Article 3(3) of the GG. ${ }^{29}$

\footnotetext{
${ }^{25}$ Berit Völzmann, Gleiche Freiheit für alle!, VERFBLOG (Nov. 17, 2017), http://verfassungsblog.de/gleiche-freiheitfuer-alle-zur-freiheitsrechtlichen-begruendung-des-bverfg-in-der-entscheidung-zur-dritten-option; Sarah Elsuni, "Harter oder weicher Sexit"?, VERFBLOG (Nov. 17, 2017), http://verfassungsblog.de/harter-oder-weicher-sexit/.

${ }^{26}$ Bundesverfassungsgericht [BVERfG] [Federal Constitutional Court], 1 BvF 1/01, BVerfGE 205, 313 (July 17, 2002).

${ }^{27}$ Anne E.H. Sanders, When, if not Now? An Update on Civil Partnership in Germany, 17 German L.J. 487 (2016); Nora Markard, Dropping the Other Shoe: Obergefell and the Inevitability of the Constitutional Right to Equal Marriage, 17 GERMAN L.J. 509 (2016).

28 Jule Mulder, eU Non-Discrimination law in the Courts: Approaches to Sex and SeXuality Discrimination in EU laW 120-39 (2017).

${ }^{29}$ See generally laura AdAMIetz, Geschlecht Als ERWARTUng (2011).
} 
A narrow reading of the current case does not necessarily broaden the scope of paragraph 3 of Article 3. After all, intersex is a biologically verifiable fact. To subsume intersex persons under the scope of paragraph 3, thus does not necessarily mean an expansion of scope that includes gender expectations, or gender identity. For many persons who experience intersex variance, it is their biological sex-not necessarily their gender-that is undetermined and does not fit within the binary structure. It is thus plausible to argue that the Constitutional Court's judgment recognizes only the non-binary identity of persons who experience intersex variance.

Nonetheless, there are several problems with such a narrow reading. First, the Constitutional Court seems to adopt a wide interpretation of sex under Article 3(3) as it refers to both, the non-binary sex as well as non-binary gender identity. Accordingly, people are not only protected from sex discrimination if their sex is neither male nor female, but also if their gender identity does not fit within the binary dichotomy. ${ }^{30}$ Thus, there are good arguments to interpret the case broadly. Accordingly, Article 3(3) of the GG on sex discrimination does not only focus on biological sex, but also includes gender identity and gender expectations. ${ }^{31}$ Second, the court focuses on the disadvantages suffered by persons who do not easily fit within the male/female dichotomy and considers their lack of recognition as a disadvantage. They either have to face gender expectations they cannotor do not want to-fulfill, or their gender is not recognized at all. The identified disadvantage is thus the "exclusion from the mainstream." ${ }^{32}$

Moreover, the Constitutional Court refers to the Court of Justice of the European Union's (CJEU) case law on trans discrimination. The CJEU has long recognized that the scope of EU non-discrimination law "cannot be confined based on the fact that a person is of one or other sex [if] discrimination is based, essentially if not exclusively, on the sex of the person concerned. ${ }^{\prime 33}$ Further, in $K B^{34}$ the court has extended the reach of Article 141 of the Treaty

\footnotetext{
${ }^{30}$ Bundesverfassungsgericht [BVERfGE] [Federal Constitutional Court], Case No. 1 BvR 2019/16, paras. 50, 58 (Oct. 10 , 2017), https://www.bundesverfassungsgericht.de/SharedDocs/Entscheidungen/DE/2017/10/rs20171010_1bvr201916.h tml.

${ }^{31}$ Ambrosi, supra note 23.

32 Nora Markard, Struktur und Teilhabe: zur gleichheitsdogmatischen Bedeutung der "dritten Option", VeRFBLOG (Nov. 14, 2017), https://verfassungsblog.de/struktur-und-teilhabe-zur-gleichheitsdogmatischen-bedeutung-derdritten-option/. For the English translation, see Nora Markard, Symposium on the 'Third Option', 'Not Man, Not Woman, Not Nothing': Structure and Participation: On the Significance of the 'Third Option' for the Equality Guarantee, BLOG OF THE IACL, AIDC (Feb. 3, 2018), https://iacl-aidc-blog.org/2018/02/03/symposium-onthe-third-option-not-man-not-woman-not-nothing-structure-and-participation-on-the-significance-of-the-thirdoption-for-the-equality-guarantee/.

${ }^{33}$ Case C-13/94 P v. S \& Cornwall Cty. Council, 1996 E.C.R. I-2143 paras. 17-21.

${ }^{34}$ Case C-117/01 K.B. v. Nat'I Health Serv. Pensions Agency, 2004 E.C.R I-541.
} 
establishing the European Community (EC) - now Article 157 of the Treaty on the Functioning of the European Union (TFEU) - to entitle a trans employee to a survival pension for her partner, even though the couple could not get married due to the UK's refusal to recognize the employee's transition-referred to in the case law as her "gender reassignment" - prior to the introduction of the UK's Gender Recognition Act $2004 .{ }^{35}$ Trans discrimination thus falls within the scope of sex discrimination; and trans individuals may not be disadvantaged either because of the fact that they are undertaking a process of transition or because they have already transitioned.

There is a clear indication that EU law on sex discrimination includes the right of gender recognition. This may be best exemplified by the CJEU's decision in Richards. ${ }^{36}$ The court held that Ms. Richards-a woman with a trans history-was entitled to all benefits provided to people of her preferred gender. The Pension Scheme's refusal to grant her a pension once she reached the pensionable age for women constituted a disadvantage and discriminated against her on grounds of sex. Without recognizing Ms. Richards' right to-legalrecognition, it is difficult to see why this would be the case. After all, she was not disadvantaged because of her process of transition. She was not treated differently compared to men who were not undergoing a process of transition - gender reassignmentrather, she was treated differently compared to other women. To consider this as an example of trans discrimination, there needs to be a right to be recognized as a woman. Otherwise, the claim could be easily dismissed on the basis that there is no disadvantage. ${ }^{37}$ EU non-discrimination law is thus able to recognize-and to remedy-claims of gender recognition and identity and has done so under the scope of sex. The German General Equal Treatment Act (Allgemeines Gleichbehandlungsgesetz, AGG) inter alia prohibiting discrimination on grounds of sex and sexual identity, certainly allows for such a broad interpretation of sex as protected characteristic in conformity with EU law. Nonetheless, whether such discrimination should be addressed under the scope of sex or sexual identity has been discussed controversially within German academia. ${ }^{38}$ The discussed case in this Note may suggest that the BVerfG is willing to adopt a broad understanding of constitutional sex discrimination that is comparable with the CJEU approach.

\footnotetext{
${ }^{35}$ Alex Harris, Non-binary Gender Concepts and the Evolving Legal Treatment of UK Transsexed Individuals, 13(6) J. INT'L. WOMEN'S STUD. 57 (2012).

${ }^{36}$ See Case C-423/04 Richards v. Sec'y of State for Work and Pensions, 2006 E.C.R. I-3585; see also Opinion of Advocate General Bobek, Case C-451/16 M.B. v. Sec'y of State for Work and Pensions (Dec. 5, 2017).

${ }^{37}$ Mulder, supra note 28 , at $47-54$.

${ }^{38}$ For an overview, see Mulder, supra note 28 , at 122-23.
} 


\section{Contextualizing the Judgment of the Court}

\section{Gender Outside the Male-Female Box: Notable Reforms and Developments}

Analyzing the judgment of the German Constitutional Court through an international and comparative law lens, there are a number of important-and welcome-aspects to note.

\section{Validating Identities Beyond Man and Woman}

The decision is a powerful acknowledgement of identities beyond the gender (and, potentially, biological) binary. It offers symbolic recognition to what remains, even in Germany, a deeply marginalized population. Around the world-despite growing public awareness of sexual diversity-persons who experience a preferred legal sex outside male/female dichotomies confront social prejudice and identity erasure. ${ }^{39}$ While law-makers and the general population increasingly embrace or accept persons who transition to a preferred male or female sex, there is still deep skepticism-and sometimes outright rejection- of self-identification beyond man and woman. Such identification is dismissed as unstable, ${ }^{40}$ unreal, ${ }^{41}$ overtly political, ${ }^{42}$ or as a mere intellectualization of legal sex. ${ }^{43}$ Indeed, even among binary trans communities, there is often explicit or implicit, disregard of nonbinary sex categorization, which some trans individuals consider as both impractically complicated ${ }^{44}$ and strategically unhelpful. ${ }^{45}$

\footnotetext{
${ }^{39}$ Dorian Needham, A Categorical Imperative? Questioning the Need for Sexual Classification in Québec, 52(1) LES CAHIERS DE DROIT 71, 73 (2011); Sonia Katyal, The Numerous Clausus of Sex, 84 U. CHI. L. ReV. 389, 405 (2017). See generally VIC Valentine, Non-BinaRY PeOPLE'S EXPeRIenCES IN THE UK (2016), https://www.scottishtrans.org/wpcontent/uploads/2016/08/Report-final.pdf.

${ }^{40}$ Jack Monroe, I'm a Little Bit Female and a Little Bit Male. Finally, I Fit in my Skin, THe Guardian (May 19, 2016), https://www.theguardian.com/commentisfree/2016/may/19/jack-monroe-little-bit-male-little-bit-female;

Siobhan Fenton, "A Hole in Your Chest Where Gender Used to Be": Being Non-binary in the UK, THE INDEPENDENT (Sept. 21, 2016), http://www.independent.co.uk/news/uk/home-news/what-does-non-binary-mean-what-its-liketo-not-have-a-male-female-gender-a7317086.html.

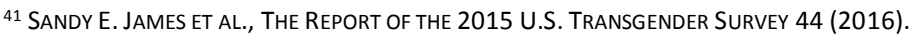

${ }^{42}$ Terry S Kogan, Transsexuals and Critical Gender Theory: The Possibility of a Restroom Labelled "Other", 48 Hastings L.J. 1223, 1224 (1996); Murray Couch et Al., TRAnZnation: A Report on the Health AND Wellbeing of Trans People in Australia ANd New Zealand 69 (2007).

${ }^{43}$ Genny Beemyn \& Susan Rankin, The Lives of Transgender People 152 (2011).

${ }^{44}$ Megan Davidson, Seeking Refuge under the Umbrella: Inclusion, Exclusion, and Organising within the Category Transgender 4(4) SEXUALITY RES. AND SOC. POL'Y 60, 66 (2007); Amy McCrea, Under the Transgender Umbrella: Improving ENDA's Protections 15 GEO. J. GENDER AND L. 543, 556 (2014).

${ }^{45}$ Patricia Gagne, Richard Tewksbury \& Deanna McGaughey, Coming Out and Crossing Over: Identity Formation and Proclamation in a Transgender Community 11 GENDER AND Soc. 478, 501 (1997).
} 
By contrast, the Constitutional Court expressly acknowledges and validates the legitimacy of non-male and non-female identities. Engaging with the lived-experiences of non-binary populations in Germany-in particular, the significant legal, social, and economic obstacles that they encounter through non-recognition - the Court affirms that such populationslike both cisgender ${ }^{46}$ and binary-trans persons-have a right to be formally recognized in their preferred legal sex.

\section{Discrimination on the Basis of Sex Characteristics}

A second welcome feature of the Constitutional Court's decision is the application of equality-based reasoning to diverse experiences of sex and/or gender. While reliance on Article 3(3) of the GG is a significant new departure for domestic constitutional law, it also has an important novelty within wider human rights jurisprudence.

The judgment suggests that intersex variance can, and does, fall within the protected category of sex for the purposes of non-discrimination law. In recent years, a number of supra-national human rights adjudicators have incorporated trans identities into existing rights standards. As noted, the CJEU includes gender reassignment within the concept of sex for the purposes of employment non-discrimination rights, ${ }^{47}$ and this jurisprudence has now been reinforced through the Preamble to Directive 2006/54 (Recital 3). In Identoba and Ors v. Georgia, the European Court of Human Rights (ECtHR) confirmed that "the prohibition of discrimination under Article 14 of the Convention duly covers questions related to sexual orientation and gender identity' (emphasis added). ${ }^{48}$ Here, it is-in the context of the Constitutional Court's decision-interesting to note that gender identity protections should extend to non-binary populations who have an internal experience of gender, which is neither male nor female. Most recently, in the Communication Decision, $G$ v. Australia, the UN Human Rights Committee observed that "the prohibition against discrimination under article 26 [of the International Covenant on Civil and Political Rights (ICCPR)] encompasses discrimination on the basis of ... gender identity, including transgender status." ${ }^{\prime 9}$

Yet, despite this increasing engagement with trans non-discrimination claims, consideration of intersex variance remains conspicuously rare in comparative and international case law. ${ }^{50}$ By addressing intersex equality rights in such a high-profile manner, the German

\footnotetext{
${ }^{46}$ Cisgender-derived from the Latin word, "cis", meaning "on this side of" - refers to persons who self-identify with the legal sex that is assigned to them at birth.

${ }^{47}$ Case C-13/94 P v. S \& Cornwall Cty. Council, 1996 E.C.R. I-2143 para. 20.

48 Identoba \& Others v. Geor., 39 Eur. Ct. H.R. 510 (2015).

49 U.N. Human Rights Comm., G v. Austral., no. 2172/2012.

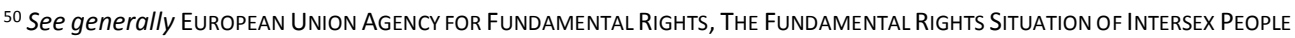
(2015), http://fra.europa.eu/sites/default/files/fra-2015-focus-04-intersex.pdf.
} 
Constitutional Court may encourage both supra-national actors, and other domestic courts, to explore discrimination grounded in non-binary experiences of biology.

At the same time, the judgment can also serve as a catalyst for the German legislature to explicitly enshrine intersex variance as a protected characteristic under nationalstatutory-equality frameworks. While it is welcome for the Constitutional Court to acknowledge intersex within existing sex discrimination structures, there may be reasons to prefer using a separate, independent ground for protection-if not in the constitutional context, then possibly by considering the General Equal Treatment Act.

Intersex variance-and the inequalities which individuals face because they have a-typical sex characteristics-is not the same as "sex" and "gender identity." While intersex discrimination often derives from the same patriarchal and biologically essentialist norms, which oppress female-identified and trans persons, it is also qualitatively different. In the UK, advocates have noted the transformative impact of removing trans discrimination from underneath a sex equality umbrella and acknowledging gender reassignment as a standalone, protected characteristic in the Equality Act 2010. Various options are available. For example, Article 19(a) of Malta's Gender Identity, Gender Expression and Sex Characteristics Act of 2015 prohibits "the treatment of a person in a less favourable manner" because of "gender identity, gender expression, or sex characteristics" (emphasis added).

The Constitutional Court's judgment is also novel in that it actually uses equality-based reasoning to resolve a dispute concerning gender diversity. In doing so, the Constitutional Court not only further develops its own prior case law on trans rights, it also departs from the standard jurisprudence of the European Court of Human Rights. While as noted, the ECtHR has incorporated trans lives into Article 14 of the European Convention on Human Rights (ECHR) protections, ${ }^{51}$ it has rarely-if ever-applied non-discrimination arguments to legal sex recognition. The Strasbourg judges have acknowledged extensive rights for trans persons to be affirmed in their preferred legal sex, ${ }^{52}$ including without a requirement to submit to sterilization..$^{53}$ However, that entitlement has arisen almost exclusively from considerations of private life under Article 8 of the ECHR. A primary criticism of the ECtHR's ruling in Hämäläinen v. Finland-rejecting a challenge to Finland's divorce requirement under Article 8 of the ECHR-is the extent to which the European Court failed to substantively address the discriminatory aspects of forced divorce. ${ }^{54}$

\footnotetext{
${ }^{51}$ Identoba 39 Eur. Ct. H.R. at para. 96.

52 Goodwin v. U.K, 35 Eur. H.R. Rep. 18 (2002); L v. Lith., 46 Eur. H.R. Rep. 22 (2008).

53 A.P., Garcon \& Nicot v. Fr., App. Nos. 79885/12, 52471/13 \& 52596/13 (April 6, 2017), http://hudoc.echr.coe.int/eng?i=001-172913.

${ }^{54}$ See, e.g., Hamalainen v. Fin., 1 FCR 379 (2015) (Sajo, J., Keller, J. \& Lemmens, J. dissenting).
} 
The German Constitutional Court's decision is evidence that questions of gender diversity can-and should-be resolved through the application of equality-based reasoning. Along with $G$ v. Australia ${ }^{5}$ - where the UN Human Rights Committee condemned New South Wales' divorce requirement under Article 26 of the International Covenant on Civil and Political Rights (ICCPR) - the judgment may represent a new trend towards greater nondiscrimination protection for trans and intersex populations.

\section{3. "Personal Identity"}

A final notable aspect of the Constitutional Court's judgment is its extension of personal identity jurisprudence to non-binary experiences. While the right to personal identity is wellestablished in German Constitutional law, it is also increasingly apparent in supra-national explorations of trans identification. In their case law on trans rights, both the UN Human Rights Committee and the ECtHR have emphasized personal identity as a core aspect of privacy and private life. ${ }^{56}$ Both institutions have relied upon the free expression and development of personal identity as a key justification for legal sex recognition. ${ }^{57}$ Taken to a logical endpoint, a right to legal recognition, which is grounded in personalized experiences of sex, should embrace identities beyond male and female-at least to the extent that persons genuinely experience themselves as falling outside binary categorization. Yet, within the current-limited-jurisprudence, neither the UN Human Rights Committee nor the ECtHR has confronted-or affirmed-petitioners outside the binary framework. ${ }^{58}$ The German Constitutional Court may provide persuasive reasoning when, not if, non-binary persons seek to enforce rights through either the ICCPR or the European Convention.

\section{Outstanding Questions and Unintended Consequences}

The judgment of the Constitutional Court is not, however, without critique or questions. In particular, three areas require further consideration or clarification: (1) Engagement with the lived-realities and priorities of intersex variance; (2) the potential application of the decision beyond intersex variance; and (3) possibilities for complying with the ruling of the court.

\footnotetext{
55 U.N. Human Rights Comm., G v. Austral., no. 2172/2012 at paras. 7.11-15.

${ }^{56}$ See id. at para 7.2; Goodwin, supra note 52, at para. 90.

${ }^{57}$ U.N. Human Rights Comm., G v. Austral., no. 2172/2012 at para. 7.2; Goodwin, supra note 52, at para. 90.

${ }^{58}$ See U.N. Human Rights Comm., G v. Austral., no. 2172/2012 at para. 7.2; Goodwin, supra note 52, at para. 90; see also Schlumpf v. Switz., App. No. 29002/06 (Jan. 8, 2009); L, supra note 52; AP, Garcon \& Nicot, supra note 53.
} 


\section{Lived-Realities and Priorities}

The Constitutional Court's decision is welcome for the extent to which it acknowledges nonbinary and intersex populations. In comparative terms, the judgment is a landmark affirmation of those who have non-binary sex and biological realities. Yet, in focusing rigidly on the subject of legal recognition, it is questionable whether the Court addresses the actual priorities of persons who experience intersex variance.

Within intersex communities-both in Germany and around the world-there is often a certain ambivalence towards legal sex recognition, particularly non-binary affirmation. This ambivalence reflects the fact that, as noted, many individuals, who experience intersex, selfidentify as male or female. ${ }^{59}$ Although some intersex persons may apply for legal sex recognition during their life ${ }^{60}$-especially where they were assigned an incorrect identity at birth-formal acknowledgement of another sexed identity, particularly a legal category beyond man and woman, is frequently not a priority. In 2013, and reaffirmed in 2017, ${ }^{61}$ the Third International Intersex Forum specifically recommended that intersex children should be raised in a binary sex, with the possibility of easily transitioning at a later date if desired ${ }^{62}$

The ambivalence is also indicative that, for many people, a greater concern is reducing the rate of genital normalizing surgeries. ${ }^{63}$ These procedures are non-therapeutic interventions, which healthcare professionals-including doctors in Germany ${ }^{64}$-perform on newborn infants to assign them to a binary sex classification. Intersex advocates argue that such

\footnotetext{
${ }^{59}$ See, e.g., Intersex Society of North America, Does ISNA Think Children With Intersex Should Be Raised Without a Gender, or in a Third Gender?, http://www.isna.org/faq/third-gender (last visited Dec. 30, 2017); Grietje Baars, The Politics of Recognition and the Limits of Emancipation Through Law, VerfBLOG (Nov. 29, 2017), http://verfassungsblog.de/the-politics-of-recognition-and-the-limits-of-emancipation-through-law/.

${ }^{60}$ Dan C. Ghattas, Human Rights Between the Sexes: A Preliminary Study on the Life Situations of Inter individuals 47 (2013).

61 4th International Intersex Forum - Media Statement, OII EUR. (Apr. 26, 2017), https://oiieurope.org/4thinternational-intersex-forum-media-statement/.

${ }^{62} 3$ rd International Intersex Forum, ILGA EUR. (Dec. 1, 2013), https://www.ilga-europe.org/what-we-do/ouradvocacy-work/trans-and-intersex/intersex/events/3rd-international-intersex-forum.

${ }^{63}$ Anne Tamar-Mattis, Exceptions to the Rule: Curing the Law's Failure to Protect Intersex Infants, 21 BeRKELEY J. GENDER, L. \& JUSTICE 59 (2006); Elisabeth McDonald, Intersex People in Aotearoa New Zealand: The Challenges for Law and Social Policy: Part I: Critiquing Gender Normalising Surgery, 46 VICTORIA U. WeLLINGTON L. REV. 705 (2015); Aileen Kennedy, Fixed at Birth: Medical and Legal Erasures of Intersex Variations, 39 U. NEW SOUTH WALES L.J 813 (2016); Jo Bird, When Sex Means Condition or Impairment: Evaluating the Human Rights of Transgender and Intersex Peoples, 5 SOUthern Cross U. L. ReV. 1 (2001).

${ }^{64}$ German InStitute for Human Rights, Gender Diversity in LAW: The Status Quo and the DeVelopment of Regulatory MOdels FOR RECOGNIZING AND PROTECTING GeNDER DIVERSITY 15 (2017), http://tbinternet.ohchr.org/Treaties/CAT/Shared\%20Documents/DEU/INT_CAT_NGO_DEU_47_8558_E.pdf.
} 
surgeries constitute a gross violation of bodily integrity and have a lasting physical and emotional impact on intersex populations. ${ }^{65}$ It may be instructive that the last high-profile constitutional court exploration of intersex-a celebrated series of judgments issued by the Constitutional Court of Colombia in the late 1990s-focused exclusively on youth medical processes, without reference to alternative sex classifications. ${ }^{66}$

The Constitutional Court's judgment-like section 22(3) of the PStG-does little to counteract genital normalizing surgeries, although, of course, the Court was not specifically asked to address that issue. While it creates a space outside binary gender norms, it will not ensure-unless the German legislature simultaneously adopts a ban on non-therapeutic interventions, similar to the prohibition currently operating in Malta ${ }^{67}$-that persons can inhabit that space while fully enjoying their bodily autonomy rights. ${ }^{68}$ In developing a practical response to the Court, parliamentarians must be conscious to properly engage with all concerns of individuals who experience intersex variance.

\section{Scope of Application}

A second consideration-which is less of a critique than a question-relates to the appropriate scope of the judgment. There remains-as noted in Section B-some uncertainty as to what role biology plays in the Constitutional Court's decision.

On the one hand, in their judgment, the Constitutional Court judges are addressing the specific fact-scenario of an intersex person and placing-to different degrees-emphasis upon that person's bodily traits. As such, there is an argument that, narrowly construed, the Court's decision requires no more than that the German legislature open up a third sex option for individuals who experience intersex variance. On the other hand, however, the Constitutional Court does-throughout its reasoning-broadly interpret non-binary status; observing how individuals can exist outside both biological and gender dichotomies. To the

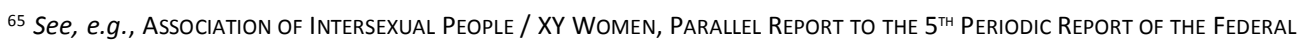
Republic of Germany on the Convention against Torture, and Other Cruel, Inhuman or Degrading treatment or PUNISHMENT

(CAT), http://tbinternet.ohchr.org/Treaties/CAT/Shared\%20Documents/DEU/INT_CAT_NGO_DEU_47_8558_E.pdf (last visited May 8, 2018); AMnesty INTERNATIONAL, FIRST, Do No HARM: ENSURING THE RIGHTS OF CHILDREN BoRN INTERSEX, https://www.amnesty.org/en/latest/campaigns/2017/05/intersex-rights/ (last visited May 8, 2018).

${ }^{66}$ Corte Constitucional [C.C.] [Constitutional Court], SU-337/99 (May 12, 1999) (Colom Corte Constitucional [C.C.] [Constitutional Court], T-551/99 (Aug. 2, 1999) (Colom.); see also Robert Hupf, Allyship to the Intersex Community on Cosmetic, Non-Consensual Genital "Normalising Surgery", 22 WM. \& MARY J. WOMEN AND L. 73, 98-100 (2015); Julie A Greenberg \& Cheryl Chase, Background of Colombia Decisions, INTERSEX SOCIETY OF NORTH AMERICA (1999), http://www.isna.org/node/21.

${ }^{67}$ Gender Identity, Gender Expression and Sex Characteristics Act, s. 14 (2015) (Malta).

${ }^{68}$ GERMAN INSTITUTE FOR HUMAN RIGHTS, supra note 64, at 5.
} 
extent that the opinion of the Court is grounded in a wide, multi-faceted understanding of non-binary experiences, surely the German government must accommodate non-male and non-female experiences of gender, even in the absence of a-typical sex characteristics.

Answering which of these two possible interpretations the Constitutional Court intended has important consequences. Tying third sex options to bodily characteristics-for example, only intersex persons can be recognized outside male and female-clearly excludes persons who, although having a sex identity beyond the binary, experience typical male or female sexed traits. Among non-intersex populations, there is a growing minority who, ${ }^{69}$ irrespective of their bodies, experience a gender, which does not fall into either man or woman classifications.

If the Constitutional Court's reasoning is contingent upon intersex variance, these latter persons will be excluded from accurate sex recognition. There will be no mechanism by which the German State can acknowledge their preferred gender. In such circumstances, there may even be discrimination on the basis of sex-as defined by the Constitutional Court in its judgment. Non-binary persons, who have intersex traits, will be formally acknowledged in their preferred legal sex, whereas no such right will vest in non-binary persons who experience typical sexed bodies. This is, ironically, the very type of discriminatory treatment, which the Constitutional Court purports to eradicate in its judgment.

In developing a framework for non-binary legal sex categories, the legislature should prefer an expansive interpretation of the Constitutional Court's reasoning. German lawmakers should incorporate all persons who fall outside male-female gender norms. Such a model already exists in jurisdictions - such as California ${ }^{70}$ and New Zealand ${ }^{71}$ - where non-binary birth certificates and " $X$ " passports are available to individuals, irrespective of whether they experience intersex variance.

Conditioning access to the alternative sex category on the existence of intersex variance would also be inconsistent with the Constitutional Court's prior case law on trans recognition. Allowing persons to obtain non-binary sex categorization because they experience ambiguous, or non-binary, bodily characteristics implies that physiology, or at least an individual's sexed-physiology, determines legal identity. However, such reasoning

\footnotetext{
${ }^{69}$ Studies from around Europe and the United States have-in the past decade-consistently shown that the number of individuals-either trans or otherwise-who identify as non-binary are consistently growing. See, e.g., Vic VAlentine, NON-BINARY PeOPLE'S EXPERIENCES IN THE U.K. (2016); Christina Richards et al., Non-binary or Genderqueer Genders, 28 INT'L REV. OF PSYCHIATRY 95 (2016).

70 See S.B. 2017 179, Leg. https://leginfo.legislature.ca.gov/faces/billNavClient.xhtml?bill_id=201720180SB179.

71 Information about Changing Sex/Gender Identity, IDENTITY AND PASSPORTS (Sept. 29, 2016) https://www.passports.govt.nz/what-you-need-to-renew-or-apply-for-a-passport/information/.
} 
conflicts with the Court's earlier pronouncements on physical intervention as a precondition for legal sex recognition.

As noted, in 2011, the Constitutional Court permitted a female-identified complainant to be formally acknowledged in her preferred sex without submitting to surgery or sterilization. ${ }^{72}$ For the Court, involuntarily medicalizing applicants for recognition was incompatible with, inter alia, the right to physical integrity. ${ }^{73}$ Implicit-or perhaps even explicit-in the 2011 judgment is a concession that, although healthcare professionals may de facto use physical characteristics to assign legal sex in infancy, such characteristics are not determinative of legal sex. For example, trans women may be recognized as female even where they retain their penis.

There are many practical justifications for such an approach, not least the inability of some trans persons-for social, health, age, religious, financial, medical, and familial reasons-to undertake a medical transition. ${ }^{74}$ The 2011 judgment, largely replicated by the ECtHR in the recent $A P$, Garçon and Nicot v. France litigation, ${ }^{75}$ ensures that formal acknowledgment is not limited to applicants with health, age, and financial privilege. Yet, to the extent that the Constitutional Court might ground non-binary legal recognition in experiences of intersex variance, this would effectively tie formal acknowledgement to having certain body features. A preferable reading of the Constitutional Court's judgment-and one, which appears more consistent with the Court's existing trans case law-is that the decision extends non-male and non-female legal status to all persons who have a sex identity beyond man and woman categorization.

\footnotetext{
72 See Bundesverfassungsgericht [BVERFGE] [Federal Constitutional CourT], 1 BVR 3295/07, BVerfGE 128, 109 (Jan. 11, 2011); see also Anatol Dutta, The Legal Status of Transgender and Transsexual Persons in Germany, in THE LEGAL Status of Transgender and Transsexual Persons 207-21 (Jens M Scherpe ed., 2015).

${ }^{73}$ See Bundesverfassungsgericht [BVERFGE] [Federal Constitutional Court], 1 BVR 3295/07, BVerfGE 128, 109 (Jan. 11, 2011).

${ }^{74}$ Alice Newlin, Should a Trip from Illinois to Tennessee Change a Woman into a Man? Proposal for a Uniform Interstate Sex Reassignment Recognition Act, 17 COLUM. J. GENDER \& L. 461, 465 (2008); Olga Tomchin, Bodies and Bureaucracy: Legal Sex Classification and Marriage-Based Immigration for Trans* People, 101 CALIF. L. REV. 813, 843 (2013); Stephanie Markowitz, Change of Sex Designation on Transsexuals' Birth Certificates: Public Policy and Equal Protection, 14 CARDOZO J.L. \& GeNDER 705, 707, 710 (2008); Harper Jean Tobin, Against the Surgical Requirement for Change of Legal Sex, 38 CASE WESTERN RES. J. INT'L L. 393, 401 (2006); Robyn Brammer \& Misty M. Ginicola, Counselling Transgender Clients, in AfFIRMATIVE CounseluING WITH LGBTQI+ PeOPLE 186 (Misty M. Ginicola, Cheri Smith, Joel M. Filmore eds., 2017).
}

${ }^{75}$ AP, Garcon \& Nicot, supra note 53. 


\section{Implementing Sex Categories Beyond Male and Female}

The final difficulty-which arises from the Constitutional Court's judgment-concerns how the German legislature is to achieve the proposed result. The Court has identified two possible solutions: (1) Introducing an alternative third sex classification; or (2) abolishing the requirement to register legal sex. Neither option is without critique.

The first-perhaps politically preferred-strategy to embrace non-binary identities involves establishing an alternative sex category into which all non-male and non-female persons may self-select. In jurisdictions, such as Nepal, ${ }^{76}$ India, ${ }^{77}$ and Pakistan, ${ }^{78}$ the superior courts have acknowledged a right for individuals to be formally recognized in a third sex classification. Where individuals are neither man nor woman, and where they desire more than the nullum envisaged by Section 22(3) of the PStG, an alternative legal sex offers a workable solution.

There are, however, at least two problems with the Constitutional Court's proposed third sex. As a framework for non-binary recognition, third categorization is both overly-inclusive and overly-exclusive. On the one hand, an alternative sex status is likely to group together a multiplicity of different-possibly oppositional-sex identities, becoming nothing more than a catch-all repository for every non-standard identification. ${ }^{79}$ On the other hand, however, a third sex will also continue to exclude those non-binary persons who experience a fluid or fluctuating gender, and for whom a third rigid classification is no more helpful than the existing male and female options. ${ }^{80}$

In addition, there is no sense from the Constitutional Court's judgment as to how a third identity option would operate in practice. Legal sex does not exist in a vacuum. It is linked to numerous social, economic, and political systems throughout Germany-as it is in other

\footnotetext{
${ }^{76}$ Supreme Court of Nepal, Writ No. 917, 2064 BS (2007 AD) (Dec. 21, 2007).

77 National Legal Services Authority (NALSA) v Union of India et al., (2014) Supreme Court of India, Writ Petition (Civil) No. 400 of 2012 (Apr. 15, 2014).

${ }^{78}$ Supreme Court of Pakistan, Constitution Petition No. 43 of 2009 (Mar. 22, 2011).

${ }^{79}$ Surya Monro, Beyond Male and Female: Poststructuralism and the Spectrum of Gender, 8 INT'L J. TRANSGENDERISM 3, 18 (2005); Theodore Bennett, "No Man's Land": Non-Binary Sex Identification in Australian Law and Policy, 37 U. NEW SOUTH WALES L.J. 847, 858 (2014).

80 Maria Pahl, Immutability of Identity, Title VII, and the ADA Amendment Act: How Being "Regarded As" Transgender Could Affect Employment Discrimination, 3 DE PAUL J. WOMEN, GENDER \& L. 63, 68 (2014); Sarah Marsh, The Gender-fluid Generation: Young People on Being Male, Female or Non-binary, THE GUARDIAN (Mar. 23, 2016), https://www.theguardian.com/commentisfree/2016/mar/23/gender-fluid-generation-youngpeople-male-femaletrans. Chau and Herring write that where current gender standards "unreasonably restric[t] people's identity into one of two sexes, it becomes hard to deny that restricting people to three identities is open to identical objections." See P-L Chau \& Jonathan Herring, Defining, Assigning and Designing Sex, 16 INT'L J.L., PoL'Y \& FAM. 327, 356 (2002).
} 
jurisdictions - all of which operate on the basis of dichotomized, binary sex. It may not be particularly difficult for the German legislature to register non-binary individuals in a third sex. Nonetheless, for that alternative registration to have any practical meaning, all the other sex-related services and facilities in Germany would also have to expand their sexedlenses. Widening sex registration requires a recalibration of how sex operates across all aspects of German society. What, for example, is the relevance of a third registration category if public accommodations-such as locker rooms and restrooms-remain anchored to a male/female binary? In its recent Consultation Paper on legal gender recognition reform in Scotland, the Scottish Government concedes the many consequential changes that would also have to take place in other areas of law if non-binary options would be implemented. ${ }^{81}$ While the Constitutional Court has offered a compelling justification why a third sex categorization is necessary, the judgment is not a roadmap for how such categorization can be achieved. Making this determination arguably falls more appropriately within the competence of the legislature; the Court identifies the rights, but democratically elected parliamentarians must shape reform. What is clear, however, is that realizing an overarching, fully inclusive third legal sex is a significant, practical hurdle, which German lawmakers-before they can satisfy the Constitutional Court's requirements-will have to surmount.

The second solution, which the Constitutional Court proposes, is abolishing the requirement for registered legal sex. If no person has to be assigned a sexed identity, non-binary persons cannot experience discrimination because they fall outside male and female categorization. For many persons-both trans and cisgender, who see de-registration as a means of challenging historical gender patriarchies-detaching gender from legal registration is an optimal strategy for addressing numerous sex-related problems. ${ }^{82}$

Like the introduction of a third sex option, however, abolishing sex registration raises important difficulties. From a practical perspective, such an approach is likely to encounter opposition from both cisgender and trans populations. While many binary-identified persons would sympathize with individuals who cannot register a sex status beyond man and woman, they may resist any solution involving the forfeit of their own registration.

\footnotetext{
81 Scottish Government, Review of the Gender Recognition Act 2004 - A Consultation, 7.23-.29 (2017) https://consult.gov.scot/family-law/review-of-the-gender-recognition-act-2004/user_uploads/sct10172517581_gender_p4--3-.pdf (last visited May 8, 2018).

82 Riki AnNe Wilchins, Read My lips: Sexual SubVersion And the end of Gender 16 (1997); Martine Rothblatt, The Apartheid of SEX: MANifESTO ON THE FREEdom OF GENDER 103 (1996).

82 Elizabeth Reilly, Radical Tweak - Relocating the Power to Assign Sex - From Enforcer of Differentiation to Facilitator of Inclusiveness: Revising the Response to Intersexuality, 12 CARDOZO J.L. \& GENDER 297, 332 (2005); Susan Stryker, Undoing Sex Classification can Provide Justice, N.Y. TIMES (Oct. 19, 2014), http://www.nytimes.com/roomfordebate/2014/10/19/is-checking-the-sex-box-necessary/undoing-sexclassification-can-provide-justice; Miqqi Alicia Gilbert, Defeating Bigenderism: Changing Gender Assumptions in the Twenty-first Century, 24 HYPATIA 93, 103 (2009).
} 
Although for some communities, legal sex is a significant social and legal impediment, many others-perhaps the majority of persons-welcome it as an inevitable and positive affirmation of status.

In addition to binary support for registration, there is also the question as to whether-even from a feminist perspective-policy-makers should want to de-gender the legal system. While there is little doubt that, as a matter of history, in both Germany and farther afield, legal sex categories have been used to enforce patriarchal norms, they are also a primary means to counteract existing social, political, and economic inequalities. ${ }^{83}$ Affirmative action, anti-discrimination statutes, and gender-conscious criminal offences are all examples of how law can be used to address persisting male/female inequities. De-emphasizing gender as a legal category will not suddenly erase practices of sex-based discrimination; a sex-blind legal system does not guarantee a sex-blind society. On the contrary, the only likely result will be a legal system, which is less well equipped to remedy sex-related discrimination when it arises. ${ }^{84}$

A preferable solution-instead of the full de-registration of gender-would be to carefully identify those areas of law where legal sex retains an objective relevance, and to engage in processes of de-emphasis where no such relevance can be found-for example, moving towards policies of parental leave, etc. In Australia, the federal government has recommended that officials record gender only where necessary, ${ }^{85}$ and a similar policy has recently been promoted by the UK's House of Commons Select Committee on Women and Equalities. $^{86}$

\footnotetext{
83 Government of Australia, Australian Government Guidelines on the ReCognition of SeX ANd Gender 8 (2015) https://www.ag.gov.au/Publications/Documents/AustralianGovernmentGuidelinesontheRecognitionofSexandGe nder/AustralianGovernmentGuidelinesontheRecognitionofSexandGender.PDF; Anna James Neuman Wipfler, Identity Crisis: The Limitations of Expanding Government Recognition of Gender Identity and the Possibility of Genderless Identity Documents, 39 HARV. J.L. \& GENDER 491, 539 (2016); Linda C McClain, Categorizing by Sex is a Remedy for Discrimination, N.Y. TIMES (Oct. 20, 2014), http://www.nytimes.com/roomfordebate/2014/10/19/ischecking-the-sex-box-necessary/categorizing-by-sex-is-a-remedy-for-discrimination; Judith Lorber, Using gender to Undo Gender: A Feminist Degendering Movement, 1 FEMINIST THEORY 79, 90 (2000).

${ }^{84}$ Marie Gustafsson Sendén, Emma Aurora Bäck \& Anna Lindqvist, Introducing a Gender-neutral Pronoun in a Natural Gender Language: The Influence of Time on Attitudes and Behavior, 6 FrontIERS IN PSYCHOL. (2015), http://journal.frontiersin.org/article/10.3389/fpsyg.2015.00893/full. According to Vade, "[i]f we act as if gender does not exist, then we act as if sexism and transphobia do not exist and so reinforce the privilege of ... in particular, male genders." Dylan Vade, Expanding Gender and Expanding the Law: Toward a Social and Legal Conceptualization of Gender that is more Inclusive of Transgender People, 11 MICH. J. GENDER \& L. 253, 277-78 (2005).

85 GOVERNMENT OF AUSTRALIA, supra note 83 , at 5.

${ }^{86}$ House of Commons Select Committee on Women And Equalities, Transgender Equality (2016).
} 


\section{Conclusion}

The recent judgment of the Constitutional Court represents a landmark moment-both for German domestic law and for comparative gender rights. The judges have joined only a handful of other global actors-including the Californian and Maltese legislatures, and the Indian and Nepalese Supreme Courts - to acknowledge the possibility of legal categorization outside male and female.

In many respects, the reasoning of the Court is striking for its progressive outlook. The judgment embraces a wide interpretation of personal identity, fully legitimizing internal developments, which stray beyond man and woman. The Constitutional Court has also expanded the operation of existing Constitutional equality frameworks, using the principle of non-discrimination to censure insufficient sex recognition laws and extending the benefit of sex equality to non-male and non-female experiences.

Moving forward, the decision has the potential to reshape sex structures across Germany's legal system, and may potentially inspire similar changes throughout the Council of Europe. In March 2018, Austria's Constitutional Court announced that it too would consider whether there is an obligation to recognize a non-male and non-female sex categorization. On an initial review, the Austrian judges suggested that forcing individuals into binary sex classes may infringe privacy rights under the ECHR. ${ }^{87}$

Yet, important questions about the precise scope of the German Constitutional Court's reasoning remain. Ultimately, whether the judgment meaningfully affects existing legal rules will depend upon which measures lawmakers choose to adopt in order to realize its aims.

87 Verfassungsgerichtshof [VFGH] [Austrian COnstitutional COURT] Mar. 14, 2018, E 2918/2016-29, https://www.vfgh.gv.at/downloads/VfGH Pruefungsbeschluss E 2918-2016 unbest Geschlecht ano.pdf. 
